\title{
HIJANETICS (HIJAIYAH AND ENGLISH PHONETICS) IN EFL PRONUNCIATION CLASSES: A PARTICIPATORY ACTION RESEARCH
}

\author{
Shafrida Wati \\ IAIN Langsa \\ shafrida.waty@gmail.com
}

\section{ABSTRACT}

This study explored the use of sounds association of Hijaiyah (Arabic Alphabets) and English phonetics (HIJANETICS) in teaching pronunciation to students who learn English as a Foreign Language, especially in Aceh context. It aimed at overcoming the learners' difficulties in producing English sounds, enhancing their communicative competency, and also promoting an alternative approach to teach pronunciation for teachers. The researcher worked with four English teachers of Madrasah Ulumul Quran (MUQ) Langsa, Aceh Province, whom were selected purposively. Observation and in-depth interview were conducted to obtain the results of the research. The findings revealed that phonetics training by associating the sounds to Hijaiyah (Arabic Alphabets) improved some learners' pronunciation qualities, which were clearer and understandable. It promoted independent learning for the students since their ability to recognize phonetics symbols allow them to discover how a word is pronounced. Most importantly, it engaged and motivated them to learn the foreign language.

\section{Keywords}

Phonetics, phonemes, hijaiyah (Arabic alphabets), pronunciation

\section{INTRODUCTION}

Pronunciation, which includes aspects of sounds, stress, rythm and intonation, is one of pivotal elements to achieve speaking skill. Ur (1996) proposes that to achieve communicative skill, ones have to acquire elements of a language such as the language structure, vocabulary, comprehension 
ability and pronunciation. Speaking, basically, functions as a means of communication. Therefore, individuals require to produce clear and understandable utterances to achieve communicative goals. In the context of teaching and learning English, pronunciation considers one typical problems encountered by many students, particularly those who learn English as a Foreign Language. Majority students pronounce a word based on its spelling. Technically, pronunciation deals with producing sounds, not spelling. Students' inability to pronounce words properly reinforces their assumption that English is a difficult subject to learn. This may decreases their enthusiasm in learning the language. In several language classrooms, some students are reluctant to take part in learning activities and they become passive.

To deal with such problem, at the first stage introducing phonemes is considered an alternative as sounds' recognition and practices are the fundamental ways to enable students to pronounce English words. International Phonetic Alphabet (IPA), which represents particular English sounds are constructed to help learners to pronounce a certain word in English. It was constructed in 1988 under continuous review by the International Phonetic Association. These symbols are attached in some reputable dictionaries such as Oxford Advance Learner Dictionary, Oxford Longman Conversation Dictionary and the Cambridge English International Dictionary, Longman pronunciation dictionary and Collin English dictionary (Por \& Fong, 2011). At the next stage, the learning can be developed to reach broader aspects of pronunciation includes intonation, stress, rhythm and intonation for more comprehensive language acquisition.

To ease students learn and produce the sounds, the researcher conceptualizes the learning of English sounds by associating them with the 
sounds that closes to the students' context, bijaiyah (Arabic Alphabets). Based on the researcher's observation, there are some similarities in the procedures of producing English speech sounds and hijaiyah. Students' ability to produce bijaiyah letters is used as an approach to learn foreign language sounds. It particularly aims at helping students to build their understanding on how to produce the sounds and to enhance their pronunciations' ability. This study explores the process of teaching English, in the aspect of pronunciation, by associating English speech sounds into bijaiyah. It also describes both teachers and students' perceptions of the sounds' association in teaching and learning pronunciation.

\section{LITERATURE REVIEW}

\section{a. The Nature of Pronunciation}

Pronunciation is one of fundamental components in speaking skill. Articulated words in speaking constitute the arrangement of speech sounds produced by the organs of speech (Ramelan, 1985). Thus, proper sounds production is significant as speech processing consist of three stages; articulation, sound and perception. This indicates that pronunciation influences meaning. Furthermore, English speech sounds are classified into vowels and consonants. There are twelve vowels include /i:/, /I/, / /, /u:/,

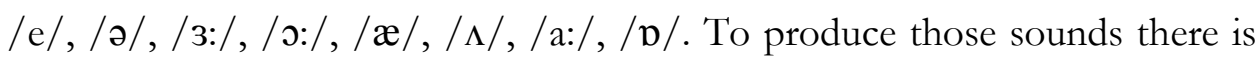
an outflow of air through the middle of the mouth and resulted vibration in the vocal cord. While, according to the position of the vocal cords the consonants are divided into voiced and unvoiced. Voiced sounds represents vibration in the vocal cord when the sounds are articulated, while the unvoiced indicates the opposite. There are 24 consonants in English; they are 


$$
\begin{aligned}
& / \mathrm{p} /, / \mathrm{b} /, / \mathrm{t} /, / \mathrm{d} /, / \mathrm{k} /, / \mathrm{g} /, / \mathrm{g} /, / \mathrm{d} /, / \mathrm{f} /, / \mathrm{v} /, / \theta /, / \mathrm{d} /, / \mathrm{s} /, / \mathrm{z} /, / \mathrm{J} / \text {, } \\
& / \mathrm{s} /, / \mathrm{h} /, / \mathrm{m} /, / \mathrm{n} /, / \mathrm{g} /, / \mathrm{l} /, / \mathrm{r} /, / \mathrm{j} /, / \mathrm{w} / .
\end{aligned}
$$

\section{b. Approaches to Teach Pronunciation}

Brown (1997) mentions that there was a significant changed towards the trend of pronunciation teaching in the middle of $20^{\text {th }}$ century. The language learning was not focused on the aspect of pronunciation. However, in the mid of 1980s, the stigma of the importance of mastering grammar was developed as a core component in language learning. To connect accuracy and fluency, pronunciation became a major concern to achieve communicative competence. Moreover, experts have conceptualized approaches towards pronunciation teaching. Laroy (1995), for example, designed approaches to teach pronunciation include holistic, synthetic and integrative. A holistic approach involves both learners' personal and physical factors. It means that, learning pronunciation requires learners' awareness of its significance and identifies challenges encountered in practice. Synthesis approach indicates that teaching pronunciation is not only focusing on the aspect of sounds but also learning the suprasegmental aspect includes stress, rhythm and intonation. While, integrative approach means integrating pronunciation exercise in learning activities. For example, students are instructed to read passages aloud. Teacher, then, integrates the pronunciation learning and reading comprehension.

The main principle in the teaching of pronunciation is to allow learners to produce intelligible pronunciation; utterances which are clear and comprehensible. Intelligibility is not a new concept in language teaching. The work of Henry Sweet in 1900, as cited in Munro (2011), formulated intelligibility as a core foundation in learning a second language. In 1949, 
Abercrombie published his popular work insisted that second language learners should notice the significance of acquiring intelligible pronunciation more than to have native-like accent. The concept is continued to be explored and reviewed at the present. A research conducted by Munro and Derwin in 2005 conclude that comprehensibility and intelligibility are two core elements to achieve communicative competence. Munro, further, notes that there are three major approaches to achieve such competence; learning phonetics, broaden knowledge about the language and conducting efforts to understand interlocutors.

\section{c. Hijaiyah (Arabic Alphabets)}

Hijaiyah is letters used to construct words in Arabic. Jamil (2015) mentions that experts have different views about the number of the letters. Some mention 30 include the letters of Lam-Alif and Hamzah. The other state 29 letters exclude Lam-Alif and 28 exclude Lam-Alif and Hamzah. Among the twenty eight letters of hijaiyah are ع ط ط ص ش س ز ر ذد خ ح جن ت ب أ (2008) highlights experts, however, agree that bijaiyah letters originated from Foenisians (Kanaan) in the NorthWest part of the Arabian Peninsula in 1100 BC. It consists of 22 letters, they

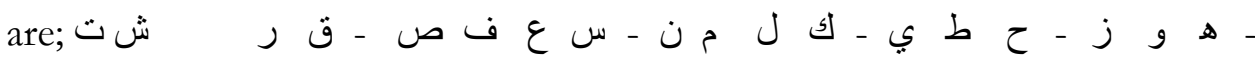
د 1 Since the Arabian adopted the letters, they added another 6

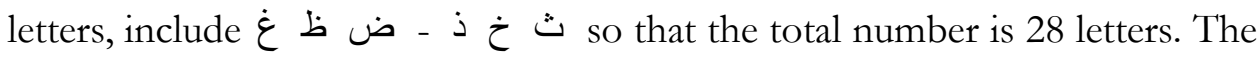
additional letters called Taraduf (similar letters). Group of the Arabic alphabets or bijaiyah is then called Al-Abjadiyah Al-Arabiyah or Arabic alphabets. Hijaiyah has been learned massively by Arabian society since the era of Khalifa Umar bin Khattab. 


\section{d. The Sounds Association of Phonemes and Hijaiyah (Arabic Alphabets)}

There are several similarities at place and manner of articulation between phonemes and bijaiyah. Connecting the sounds is expected to involve students' experience and knowledge in learning English pronunciation as well as to stimulate their enthusiasm in learning. The researcher believes that majority students in Acehnese context are familiar with hijayah (Arabic Alphabets) as they have learned them since they were kid. Hijaiyah is the foundation when somebody starts learning to recite the holy Al-quran. The following table illustrates the similarities in the manner of articulation adapted from Jaelani (2015) and Indriani (2001):

\begin{tabular}{|c|c|c|}
\hline Manner and place of articulation & Phonetics & Hijaiyah \\
\hline $\begin{array}{l}\text { a. Two organs approximate to such an } \\
\text { extent that the airstream passes through } \\
\text { them with friction }\end{array}$ & $\mathrm{H}$ & ه \\
\hline $\begin{array}{l}\text { b. A complete closure at some point in the } \\
\text { vocal tract, behind which the air pressure } \\
\text { builds up and can be released explosively }\end{array}$ & $\mathrm{k}, \mathrm{t}, \mathrm{d}, \mathrm{b}$ & ت, د ب, ك \\
\hline $\begin{array}{l}\text { c. The front tongue articulates with the } \\
\text { hard palate }\end{array}$ & $\mathrm{J}$ & ي \\
\hline $\begin{array}{l}\text { d. A complete closure at some point in the } \\
\text { mouth, behind which the air pressure } \\
\text { builds up }\end{array}$ & ds & ج \\
\hline $\begin{array}{l}\text { e. Two organs approximate to such an } \\
\text { extent that the airstream passes through } \\
\text { them with friction }\end{array}$ & $\int$ & ش ش \\
\hline
\end{tabular}




\begin{tabular}{|c|c|c|}
\hline $\begin{array}{l}\text { f. A partial closure is made at some point in } \\
\text { the mouth, the air-stream being allowed } \\
\text { to escape on one or both sides of the } \\
\text { contact }\end{array}$ & $\mathrm{L}$ & J \\
\hline $\begin{array}{l}\text { g. The tongue tip taps against the alveolar } \\
\text { ridge }\end{array}$ & $\mathrm{R}$ & J \\
\hline $\begin{array}{l}\text { h. The blade articulate with the alveolar } \\
\text { ridge }\end{array}$ & Z & j \\
\hline $\begin{array}{l}\text { i. Tounge tip and rims articulate with the } \\
\text { upper teeth }\end{array}$ & $\theta$, & ث, ظ \\
\hline j. Lower lip articulates with the upper teeth & $\mathrm{F}$ & ف \\
\hline
\end{tabular}

Table. 1 Descriptions of similarities in the place and manner of articulation

Even though not all phonetics have similar manner and place of articulation to bijiayah but the rest are resemble to the sounds of students' native language. The following table shows examples of words with the sounds association:

\begin{tabular}{|l|l|l|l|}
\hline No. & Symbols & Examples & Notes \\
\hline 1. & $/ \mathrm{p} /$ & pack/pæk/ & Produced as the letter 'p' in Bahasa \\
\hline 2. & $/ \mathrm{b} /$ & book $/ \mathrm{b}$ $\mathrm{k} /$ & Produced as sound \\
\hline 3. & $/ \mathrm{t} /$ & tea $/ \mathrm{tr}: /$ & Produced as sound \\
\hline 4. & $/ \mathrm{d} /$ & $\mathrm{mud} / \mathrm{m} \Lambda \mathrm{d} /$ & Produced as sound \\
\hline 5. & $/ \mathrm{k} /$ & $\mathrm{key} / \mathrm{kI}: /$ & Produced as sound \\
\hline
\end{tabular}


Journal of Linguistics, Literature \& Language Teaching

\begin{tabular}{|c|c|c|c|}
\hline 6. & $/ \mathrm{g} /$ & gone/gpn/ & Produced as sound 'g' in Bahasa \\
\hline 7. & $/ \mathfrak{t} /$ & watch/wotg/ & Produced as the letter of 'c' in Bahasa \\
\hline 8. & $/ \mathrm{d} / \mathrm{s} /$ & $\mathrm{Jam} / \mathbf{d g} æ \mathrm{~m} /$ & Produced as the sounds ج \\
\hline 9. & $/ \mathrm{f} /$ & free/'fri:/ & ف Produced as the sound \\
\hline 10. & $/ \mathrm{v} /$ & very/'veri/ & Produced as the letter ' $v$ ' in Bahasa \\
\hline 11. & $/ \theta /$ & three/ Ori:/ & Produced as the sound \\
\hline 12. & /ð/ & they/ ðeI/ & Produced as the sound \\
\hline 13. & $/ \mathrm{s} /$ & sorry/'spri/ & Produced as the sound \\
\hline 14. & $|z|$ & visit/'vizit/ & Produced as the sound \\
\hline 15. & $/ \mathrm{d} /$ & sugar/'Jugə/ & Produced as the sound \\
\hline 16. & $/ 3 /$ & $\begin{array}{l}\text { Pleasure } \\
\text { /plezə(r)/ }\end{array}$ & $\begin{array}{l}\text { Produced as the letter of ' } z \text { ' in Bahasa } \\
\text { with strong vibration }\end{array}$ \\
\hline 17. & $/ \mathrm{h} /$ & help/help/ & Produced as the sound \\
\hline 18. & $/ \mathrm{m} /$ & Month $/ \mathbf{m} \wedge \mathrm{n} \theta$ & Produced as the sound \\
\hline 19. & $/ \mathrm{n} /$ & next/nekst/ & Produced as the sound \\
\hline 20. & $/ \mathrm{y} /$ & $\operatorname{sing} / \sin /$ & $\begin{array}{l}\text { Produced as consonant cluster 'ng' in } \\
\text { Bahasa }\end{array}$ \\
\hline 21. & $/ 1 /$ & listen/'lisən/ & Produced as the sound \\
\hline 22. & $/ \mathrm{r} /$ & $\mathrm{red} / \mathrm{red} /$ & Produced as the sound \\
\hline
\end{tabular}




\begin{tabular}{|l|l|l|l|}
\hline 23. & $/ \mathrm{j} /$ & few/fju:/ & Produced as the sound \\
\hline 24. & $/ \mathrm{w} /$ & win/wIn/ & Produced as the sound \\
\hline
\end{tabular}

Table 2: Sounds association on producing English phonemes and Arabic alphabets (Hijaiyah).

\section{Research Method}

This research is a Participatory Action Research (PAR). Reason dan Bradbury (2008) define that PAR is a study which involve groups of people to actively collaborate to research, to make change and to solve problems. In the context of education, PAR aims at empowering individuals within the scope of school, education system and school communities. The concept is approaching a process of study in which participants work together to conduct an action-based research. This research was conducted at Madrasah 'Ulumul Quran (MUQ) Langsa, by involving the school principal, a curriculum-teacher, four English teachers and students to figure out challenges in English teaching and learning process in the academic year of 2018/2019. One of typical problems learners' experienced in learning English deals with pronunciation. Therefore, the researcher collaborated with the English teachers to facilitate the learning by introducing the concept of the sounds association.

This research employs a model of PAR conceptualized by Stringer 2007. The cycles consist of three stages, namely; look, think and action. Cresswell (2012) describes Stringer's model emphasizes on the importance of preliminary research. This includes interview, observation, documentation, noting and analyzing the data, constructing problems and informing the 
prospect problems to the institution. At 'think' stage, problems are interpreted and solutions are constructed. Last stage, 'act' is designed to find out solution toward the problem by arranging plans, setting goals, carrying out activities, and collecting supporting sources. The aims are to encourage others to perform practice and to evaluate whether the action contributes positively on solving the problem or not.

\section{RESEARCH FINDINGS AND DISCUSSIONS}

a. Teaching and learning process in the aspect of pronunciation by using sounds association of English phonetics and bijaiyah.

Result of preliminary study showed that there were 10 most difficult sounds produced by students include $/ \theta /, /$ ð/, $/ \mathrm{J} /, / \mathrm{t} /, / \mathrm{d} /, / \mathrm{z} /, / \mathrm{t} /, / \mathrm{k} /$, $/ \mathrm{v} /, / \mathfrak{x} /$ which affect on their pronunciation. The researcher and teachers focused on dealing with such problem. At the first stage, the researcher conducted a workshop for the English teachers about the use of sounds' association of hijaiyah as an alternative technique in encountering students' problems in pronunciation. The researcher provided cards and postures of bijaiyah and English phonetics as media to introduce the sounds. Both researcher and teachers, then, designed lesson plans and implemented the practice. The application of the approach is described as following:

\section{a. Activity One}

A teacher started class by asking students few questions as a warmup. Then, she instructed them to read a passage on textbook and discussed the information. She explained the concept of To be in the form of simple present, simple past, present perfect, past perfect, future and elaborate them by constructing passive sentences based on the subject + tobe + past participle 
(V3)+complement formula. Students, afterwards, are asked to construct some examples and read them a loud. Finally, the teacher noted down words with incorrect pronunciation on the white board such as answer, any, scarce, declare, coast, very, visited, village, scissors, science, scenery and scene. The teacher explained the concept of silent consonant. She highlited ' $c$ ' in scissors is silent consonant and 'sc' pronounced as 's' as the sound win bijaiyah. The teacher asked the students to practice the words. At the activity, the teacher provided drilling technique. The technique bases on behaviorism and audio-lingual approaches. It is considered as an effective technique to master pronunciation since listening and practice activities help students to remember new words and how they are pronounced (Kelly, 2000). Heinich, et al (2002) also add that exercise and repetition helps new information stored in one's long term-memory. Additionally, choral repetition exercises may contribute on developing students' confidence in practicing pronunciation as those who make mistakes will not be pointed out individually but in groups.

\section{b. Activity Two}

Teacher started class by asking students to look at two pictures, a clean and a dirty river, on the text book and instructed them to express their oipinion. She, then, asked them to read a passage on how to keep the river cleans one by one. There were many inaccuracies in students' pronunciation. Some of them even looked confuse to read. When students mispronounced a word 'river' as 'raiver', the teacher immediately exemplified the proper pronunciation and asked them to imitate and repeat. Other mistakes were at pronouncing the word 'think' and 'rubbish'. Few students pronounced it as 'tink'. She explained the word 'think' / is produced as $\dot{\omega}$ letter of bijaiyah. The teacher then elaborated other

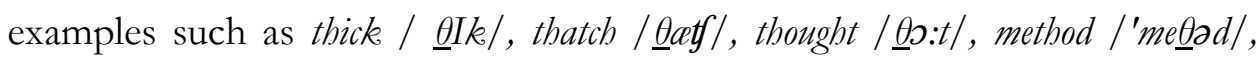


author/'ऽ: $\underline{\theta} \partial(r) /$, month $/ \operatorname{man} \underline{\theta} /$. The teacher asked to practice the sounds individually and pronounce the words. The learning, then, explored into communicative activities such as classroom discussion, role-play, and dialogues. During the learning process, the teacher provided corrective feedback on students' pronunciation. Corrective feedback plays a major role in language learning as it enhances students' understanding toward the language aspect they learned (Brown, 1997). To support this, the students need to be exposed to the concept of sounds to provide practice. Enhancing students' ability on sounds recognition and how to articulate them may develop their autonomy in learning. This is because, they can independently refer to their dictionaries to find out words that are difficult to pronounced.

\section{c. Activity Three}

Teacher began the lesson by initiating short conversation and reviewing vocabulary. She wrote lists of vocabulary on the whiteboard and asked them to read a load. The teacher, then, asked the learners to compose sentences by using the vocabulary. She explained the concept of Modal to express recommendation and suggestion such as "why don't", "what about", "you should", "you can"," do you need". Teacher paid serious attention to students who found difficulties in pronouncing words by providing examples and guiding them to repeat for several times. In this session, the teacher brought cards of phonetic symbols and bijaiyah letters to help illustrate the sounds. The aspect of pronunciation is integrated in learning English grammar.

d. Activity -Four

Teacher guided students to review vocabulary they have learnt. She sticks on posters of hijaiyah and phonetic symbols on the whiteboard and 
asked the students to look at phonetic symbols available on their dictionaryies. She explained the concept of sounds and spelling and introduced them about the symbols. The teacher showed how to produce the sounds by associating them to the sounds of bijaiyah. The teacher deal with some difficult words consisting the sounds/ $\mathfrak{g} /$ and $/ \mathrm{J} /$ such as in words chair, chocolate, chalk, time, table, first, should, she, shall, and many others. She hold two cards $/ \mathrm{J} /$ and $/$ ش/. The teacher showed how to pronounce it and elaborated the practice by giving a subject 'I should recite The Holy Quran', then she added other subject pronoun and asked students to complete the sentence.

B. Teachers and students' perspectives on the use of sound association in learning English pronunciation.

Teachers agree that pronunciation is considerably important to acquire a foreign language skill. To learn a language means to acquire its skills. To achieve the communicative skills, ones should acquire pronunciation. Nevertheless, it is one of the most problems encountered by students in learning English. Teachers admitted, in reading activities they were not only focus on developing comprehension but also often asked students to read aloud in order to facilitate practice to read English texts fluently. Sebestova (2007) highlights that teacher hold an important role in learning in particular to provide exposure towards the foreign language learning and to help the learners to produce comprehensible pronunciation. Teachers also need to include the component in learning, to provide feedbacks and to evaluate students' progress.

Teachers also noted that further efforts to stimulate students to practice the language and solved their problems in learning are needed. 
Regarding to learning to pronounce words by using the sounds association, teachers considered it is as a helpful alternative in teaching English pronunciation. One of the teachers expressed that was applicable. When the students pronounced words incorrectly, she connected the sound production to hijaiyah and facilitated practice. It helped students to produce clearer and understandable pronunciation. Results of an interview with several students also showed that they found it easier to learn pronunciation by using the sound association as they were able to pronounce letters of bijiyah and could adapted them to learn the foreign language. Another student mentioned that, she preferred to learn Arabic to English as English pronunciation is difficult. However, the sounds association approach has changed her perception that learning the pronunciation was engaging.

Learning pronunciation by associating phonetics and bijaiyah letters applies cognitivism. This believe emphasizes on learning is about changing perception and understanding. This language learning theory put learning process higher than the results of the learning itself. According to this theory, knowledge is developed through simultaneous interaction between oneself and his environment (Rosyidi and Ni'mah, 2012). More specifically, the sounds association approach conduct assimilation which represent a cognitive process. People connect their background knowledge to new information they are learning. In the learning process, students learned to produce sounds by presenting their knowledge and experience in producing bijaiyah. The manner to produce hijaiyah was assimilated to produce English phonetics which has similar sounds. 


\section{CONCLUSION}

Pronunciation is one of important components to achieve communicative skill. The common problems encountered by students in pronunciation deals with their inability to articulate sounds. Thus, to teach sounds recognition and to facilitate practice are important to support the students to develop this competency. In this research, the students' ability to produce bijiayah letters is used to help them learn to pronoun phonetics which has similar sounds. This was expected to improve the quality of their pronunciation and to contribute as an alternative for English teachers to overcome their students' problems in foreign language learning, especially pronunciation. Results indicated that most students find learning pronunciation by using the sounds association eases them to understand on how to produce the English words. Teachers also believed that the approach was practical and applicable.

\section{REFERENCES}

Brown. H. D. (1997). Teaching by Principles: An interactive approach to teaching pedagogy. New York: Pearson Education.

Creswell, W. J. (2012). Educational research: Planning, conducting, and evaluating Quantitative and Qualitative research. Fourth Edition. Boston: Pearson Education, Inc.

Heinich, R., Molenda, M., Russell, D. J., \& Smaldino, E. S. (2002). instructional media and technologies for learning. New Jersey: Pearson education

Indriani, M. I. (2001). English pronunciation. the English speech sounds theory \& practice. Jakarta: PT. Gramedia. 
Jaelani, A. (2015). Belajar buruf-buruf Hijaiyah Al-quran serta cara membacanya. Retrieved from www.halaqoh.com.

Jamil. S. (2015). Mengenal huruf hijaiyah. Retrieved from www.sofhaljamil.com

Kelly, G. (2000). How to teach pronunciation. Edinburgh: Pearson Education Limited.

Laroy, C. (1995). Pronunciation. Oxford: Oxford university press.

Munro, M. J. (2011). Intelligibility: Buzzword or buzz worthy?. In. J. Levis \& K. Le Velle (Eds.). Proceedings of the 2nd Pronunciation in Second Language Learning and Teaching Conference, Sept. 2010. (pp.716), Ames, IA: Lowa State University.

Por, F. P \& Pong, S. F. (2011). Towards transformation: The power of phonetic symbols embedded in the multi-media learning management system. English Language Teaching. 4(1), 167- 173.

Ramelan. (1985). English phonetics. Semarang: IKIP Semarang Press.

Reason, P. \& Bradbury, H. (2008). The sage handbook of action research: participative inquiry and practice. California: Sage.

Rosidi, W. \& Ni'mah, M.( 2012). Memahami konsep dasar pembelajaran bahasa Arab. Malang: UIN Maliki Press

Šebestová. S. B. (2007). Some aspects of assessing pronunciation in EFL Classes. Unpublished thesis. MASARYK UNIVERSITY

Taufiqurrochman, R. (2008). Leksikologi bahasa Arab. Malang: UIN-Malang Press.

Ur, P. (1996). A course in language teaching. Cambridge: Cambridge University Press. 